\title{
IMPLEMENTASI NILAI-NILAI DEMOKRASI DALAM PEMBELAJARAN PENDIDIKAN PANCASILA DAN KEWARGANEGARAAN DI MAN LANGKE REMBONG RUTENG NUSA TENGGARA TIMUR
}

\author{
Muhammad Nasrullah, Budiono, Agus Tinus \\ FKIP Universitas Muhammadiyah Malang, Indonesia \\ Email: nasrulruel@gmail.com
}

\begin{abstract}
ABSTRAK
Pembelajaran Pendidikan Pancasila dan Kewarganegaraann merupakan pelajaran yang diajarkan pada setiap tingkat pendidikan, oleh karana itu berdasarkan uraian dan judul skripsi ini peneliti tertarik menggali informasi dengan judul peneliti. Adapun informasi yang perlu digali informasinya adalah Kepalah Sekolah MAN Langke Rembong Ruteng Nusa Tenggara Timur, Guru PPKn, Siswa dan Siswi MAN Langke Rembong Ruteng. Tujuan penelitian ini adalah: 1 . Untuk mengetahui bentuk nilai-nilai demokrasi dalam pembelajaran Pendidikan Pancasila dan Kewarganegaraan di MAN Langke Rembong Ruteng NTT. 2. Untuk mengetahui bagaimana implementasi nilai-nilai demokrasi dalam pembelajaran Pendidikan Pancasila dan Kewarganegaraan di MAN Langke Rembong Ruteng NTT. 3. Untuk mengetahui bagaimana guru mengatasi hambatan pembelajaran Pendidikan Pancasila dan Kewarganegaraan tentang materi nilai-nilai demokrasi di Man Langke Rembong Ruteng NTT. Metode Penelitian adalah mengunakan penelitian tentang riset yang bersifat deskriptif dan cenderung menggunakan analisis Proses dan makna lebih ditonjolkan dalam penelitian kualitatif. Landasan teori dimanfaatkan sebagai pemandu agar fokus penelitian sesuai dengan fakta di lapangan. Selain itu landasan teori juga bermanfaat untuk memberikan gambaran umum tentang latar penelitian dan sebagai bahan pembahasan hasil penelitian. Hasil Penelitian adalah 1. Bentuk Nilai-Nilai Demokrasi dalam Pembelajaran Pendidikan Pancasila dan Kewarganegaraan di MAN Langke Rembong Ruteng NTT yakni Pembentukan nilai-nilai demokrasi dalam pembelajaran Pendidikan Pancasila dan Kewarganegaraan merupakan pengetahuan mencakup tentang kebebasan, serta membangun jiwa-jiwa nasionalisme, siswa dapat membentukan nilai-nilai demokrasi dalam dirinya, sekaligus menerapkannya. 2. Implementasi nilai-nilai demokrasi dalam pembelajaran Pendidikan Pancasila dan Kewarganegaraan di MAN Langke Rembong Ruteng NTT yakni mengembangkan kebebasan dalam berpendapat, yang harus ditegakkan oleh setiap siswa dan siswi MAN Langke Rembong Ruteng NTT. 3. Guru mengatasi hambatan Pembelajaran Pendidikan Pancasila dan Kewarganegaraan tentang materi milai-nilai demokrasi di MAN Langke Rembong Ruteng NTT yakni mengembangkan gagasan Pendidikan Pancasila dan Kewarganegaraan yang focus pada materi nilai-nilai demokrasi di sekolah, dan perlu dipersiapkan kemampuan guru dan tenaga kependidikan.
\end{abstract}

Kata Kunci: Implementasi, Nilai-nilai Demokrasi, Pembelajaran, Pendidikan Pancasila dan Kewarganegaraan.

\begin{abstract}
Learning Pancasila and Civics Education is a lesson taught at every level of education. Based on the description and title of this thesis, the researcher were interested in digging up information with the current research title. Also, there are some information needed to be explored which were the Head of Islamic High School in Langke Rembong Ruteng, East Nusa Tenggara, Civic Teachers, and Students of the from the school.The purpose of this research are: 1. to identify the forms of democratic values in learning
\end{abstract}


Pancasila and Civic Education in Islamic High School at Langke Rembong Ruteng in East Nusa Tenggara. 2. To identify how the implementation of democratic values in learning Pancasila and Civic Education in Islamic High School at Langke Rembong Ruteng in East Nusa Tenggara. 3. To identify how the teachers overcome the obstacle in teaching Pancasila and Civic Education with the material democratic values in Islamic High School at Langke Rembong Ruteng in East Nusa Tenggara.The Research Method used the descriptive research and more of analysis. Processes and meanings are more highlighted in qualitative research. The theoretical foundation was applied as a guide to make a focus of the research in which accordance with the facts in the field. Besides that the theoretical basis is also useful to provide an overview of the research setting and as a material for discussion of research results.Research Results are 1. Forms of Democratic Values in Learning Pancasila and Civic Education in Islamic School at Langke Rembong Ruteng in East Nusa Tenggara were the Establishment of democratic values in the learning of Pancasila and Civic education that states this is knowledge about freedom, and building the nationalism, students can form democratic values within theriself and also implement them. 2. Implementation of Democratic Values in Learning Pancasila and Civic Education in Islamic High School at Langke Rembong Ruteng in East Nusa Tenggara is the development freedom of expression, which must be upheld by every student in Islamic High School at Langke Rembong Ruteng in East Nusa Tenggara. 3. Teachers overcome obstacle to teach Pancasila and Civic Education on Democratic Values Material in Islamic High School at Langke Rembong Ruteng in East Nusa Tenggara is the development of the idea of Pancasila education and civic that focus on the material of democratic values in schools. Also the ability of teachers and educators should be prepared.

Keywords: Implementation, Democratic Values, Learning, Pancasila and Civic Education.

\section{PENDAHULUAN}

Pendidikan adalah segala sesuatu pengamalan belajar yang berlangsung dalam segala lingkungan dan sepanjang hidup. Pendidikan adalah segala unsur yang tidak dapat dipisahkan dari diri manusia dalam kehidupan sehari-hari, mulai dari anak-anak sampai beranjak dewasa dan tua. Manusia mengalami proses pendidikan yang didapatkan dari kedua orang tua, masyarakat, maupun dalam kehidupan lingkungannya. Karena dalam pendidikan suatu kebutuhan bagi manusia yang mempersiapkan sejak hari ini, hari esok untuk membekali diri di hari kemudian, sebab tanpa pendidikan manusia akan sulit berkembang dan bahkan akan terbelakang. Sehingga manusia sangat membutuhkan pendidikan melalui proses penyadaran yang berusaha untuk menyadari, menggali dan mengembangkan potensi dirinya melalui metode pengajaran atau dengan cara lain yang telah diakui oleh masyarakat, bangsa dan negara.
Dalam dunia Pendidikan tidak mengenal usia untuk belajar, dalam arti bahwa sampai usia tuapun manusia berhak mendapatkan pendidikan. Dalam pendidikan, Peranan pendidikan inilah yang sangat besar dalam memberikan dan mewujudkan manusia yang utuh dan mandiri serta menjadi manusia yang beraklak mulia dan bermanfaat bagi kehidupan masyarakat bangsa dan negara. Adanya suatu pendidikan, manusia akan menyadari dan paham bahwa dirinya itu sebagai makhluk sosial yang dikaruniai kelebihan dibandingkan dengan makhluk yang lainnya.

Bangsa dan Negara memberikan pendidikan yang kontribusi yang sangat berperan besar terhadap suatu kemajuan dalam bangsa dan pendidikan ini suatu wahana yang menjalankan dan menerjemahkan pesan-pesan UUD 1945 serta membangun watak dan karakter yang sesuai dengan apa yang diamanatkan dalam 
UUD NRI 45 dan Pancasila demi mensejahtrakan kehidupan masyarakat, bangsa dan Negara. dalam UndangUndang No. 20 Tahun 2003 menjelaskan tentang suatu Sistem Pendidikan Nasional yang harus diterapkan dalam pendidikan, menyebutkan bahwa dalam pendidikan memberikan usaha sadar untuk menyadari dalam mewujudkan suasana belajar dalam proses pembelajara agar peserta didik aktif dalam mengembangkan potensi-potensi yang ada dalam dirinya untuk memiliki jiwa-jiwa nasional, spiritual keagamaan, pengendalian diri, kecerdasan, ahlak mulia, serta keterampilan yang diperlukan dirinya, untuk memajukan masyarakat, bangsa, dan negara. Secara sederhana dapat diartikan pendidikan adalah segala usaha sadar dalam mempengaruhi peserta didik agar dapat mengembangkan potensi dalam dirinya sehingga menjadi manusia yang seutuhnya yaitu manusia yang bermoral, bertanggung jawab, dan bersosialisasi.

Pendidikan ini dapat dilakukan oleh lembaga sekolah (formal). Setiap kegiatan pendidikan hampir selalu melibatkan unsur-unsur yang terkait didalamnya. Unsur-unsur tersebut yaitu peserta didik, pendidik, tujuan, isi pendidikan, metode, dan lingkungan. Sehingga Pendidikan merupakan sebagai hak yang dimiliki oleh setiap individu manusia, yang akan memajikan generasi anak bangsa, dan telah diakui dalam konstitusi UUD NRI 1945 dalam pasal 31 ayat 1 yang menyatakan bahwasannya setiap individu masyarakat Warga Negara indonesia mempunyai hak untuk mendapatkan pendidikan. Sedangkan ayat 3 menyatakan bahwasannya pemerintah indonesia mengajukan serta mengusahakan dan menyelenggarakan satu sistem pendidikan nasional (formal) untuk meningkatkan dan menguatkan keimanan serta ketakwaan, untuk menanamkan ahlak mulia dalam rangka mensejahtrakan kehidupan masyarakat bangsa dan negara yang diatur sesuai dengan UUD NRI 45. Sehingga semua komponen-komponen bangsa baik orang dewasa, orang tua, maupun masyarakat, pemerintah bisa bertangung jawab dalam mencerdaskan bangsa melaluhi pendidikan tersebut. Karena ini merupakan satu tujuan dalam kehidupan bermasyarakat, berbangsa dan bernegara yang diamanatkan dalam pembukaan UUD NRI 45 alinea IV (empat).

Bangsa Indonesia ingin mewujudkan nilai-nilai demokrasi yaitu suatu masyarakat yang demokratis. Masyarakat demokratis atau di dalam khasanah Bahasa indonesia masyarakat madani adalah suatu masyarakat yang mengakui hak-hak asasi manusia (HAM). Masyarakat madani adalah suatu masyrakat yang terbuka dimana setiap anggotanya merupakan pribadi yang bebas dan mempunyai tanggung jawab untuk membangun masyrakatnya dengan mengakui perbedaan-perbedaan yang ada dalam masyarakatnya.

Masyarakat madani ada karena adanya suatu sistem pendidikan dalam kehidupan masyarakat, bangsa dan negara, dan dalam pendidikan ini sangat memerlukan suatu sistem nilai yang harus berbeda dengan sistim masyarakat awam dan militer. Sebab itu, perubahan dari sistim pendidikan akan merubah tingka laku masyarakat, baik itu masyarakat awam, maupun masyarakat masyarakat militer yang bersifat otoriter dalam kehidupan, dan sentralitis ini bertujuan kepada masyarakat yang mengakui akan HAM serta saling menghargai adanya suatu perbedaan antar anggotanya, dan dalam hal ini memerlukan sesuatu proses pembentukan pribadi melalui proses 
pendidikan. Salah satunya adalah pendidikan di sekolah, dimana unsur terpenting didalamnya selain guru dan siswa adalah pelajaran yang diajarkan. Pelajaran dapat dimaknai sebagai sesuatu yang diperoleh siswa di sekolah. Pada umumnya proses pembelajaran PPKn yang dilaksanakan yaitu melalui pembelajaran satu arah, yaitu ceramah, dan siswa tidak diajak untuk turut aktif, sehingga proses pembelajaran menjadi kurang menarik, karena siswa tidak memiliki tantangan dan hanya mendatangkan apa yang dikatakan oleh guru. Proses pembelajaran seperti ini akan menyebabkan proses pembentukan suasana demokrasi disekolah dalam pembelajaran PPKn menjadi gagal. Karena siswa tidak distimulus untuk memberi pendapatnya sesuai dengan tujuan pembelajaran yang diharapkan. Pendidikan formal selaku lembaga yang menerapkan sebagai nilai-nila budaya yang ada dalam kehidupan masyarakat, melalui pendidikan, tingka laku masyarakat baik itu secara individual maupun kelompok akan menerapkan ke generasi selanjutnya untuk mengimplementasikan dalam kehidupan bermasyarakat.

PPKn merupakan mata pelajaran pendidikan moral, pendidikan moral yang merupakan suatu usaha membimbing perkembangan kepribadian peserta didik yang berlandasan Pancasila. Oleh sebab itu, pendidikan PPKn di setiap lembaga pendidikan harus tetap dilakukan secara terus menerus dan berkesinambungan. PPKn juga sebagai sarana untuk mengembangkan potensi kepribadian peserta didik dengan mengangkat tema perkembangan IPTEK yang terjadi dalam lingkungan Pendidikan,

Pembelajaran PPKn diarahkan kepada upaya untuk meningkatkan pemahaman, penghayatan, dan pengamalan nilai-nilai demokrasi dan UUD NRI 1945. Kehidupan dalam dunia pendidikan sekarang ini yang disertai dengan perkembangan dunia teknologi yang semakin kompleks menuntut guru untuk dapat mengarahkan dan memotivasikan siswa dalam kegiatan yang melibatkan mereka untuk bertindak secara demokratis dengan menciptakan proses belajar mengajar yang menarik, kreatif, dan inovatif. Misalnya guru memberikan kesempatan kepada siswa untuk bertanya serta berpendapat secara demokratis, tentu ini sangat membantu memotivasi siswa untuk merealisasikan kehidupan yang demokratis dilingkungan sekolah, dan siswa mampu menerapkannya baik dilingkungan pendidikan, maupun dilingkungan keluarga, dan dalam kehidupan masyarakat.

Seiring dengan adanya kemajuan tentang ilmu pengetahuan dan teknologi, khususnya teknologi informatika yang cangih dalam perkembangan pengetauhan, maka pemerintah harus meratakan dalam sistem pendidikan formal dan mengimplementasika dalam sistem pendidikan yang akan memberikan kesejahtraan dalam pendidikan formal. Sehingga nilai-nilai demokrasi dalam pembelajaran PPKn akan dapat diwujudkan. Dengan iklim yang demikian, pendidikan mampu melahirkan calon-calon penerus pembangunan masa depan yang sabar, kompoten, mandiri, kritis, rasional, cerdas, kreatif, dan siap menghadapi berbagai macam tantangan dengan tetap bertawakal terhadap sang penciptanya. Bahwa apa yang dihadapi, apa yang menjadi kehendak Ilahi yang harus dihadapi dan disyukuri.

Sekarang ini guru bidang studi Pendidikan Pancasila dan Kewarganegaraan selalu mempunyai rintangan dalam mengimplementasikan materi dan teori, 
dalam toeri Pendidikan Pancasila dan Kewarganegaraan ini memberikan suatu dampak yang efektif dalam menghadapi rintangan, dan bertujuan untuk memberikan kesejahtraan dalam kehidupan masyarakat, berbangsa serta bernegara, sehingga teori dan materi ini bisa berkembang dan masyarakat bisa menerapkan nilai-nilai yang ada dalam teori PPKn. Melaluhi teori dan materi ini yang akan memberikan gerakangerakan yang efektit secara umum dalam sosialisasi antara masyarakat, bangsa dan negara. Pembelajaran PPKn menjadi salah satu mata pelajaran yang mempunyai berfungsi dalam menarapkan kesatuan bermasyarakat dengan didorongkan adanya jiwa-jiwa nasionaslisme, untuk mengimplementasikan suatu wadah yang menjadi regenerasi untuk menerapkan dan secara bertanggung jawab dalam menjalankannya, sehingga bisa membudayakan regenerasi jiwa muda dalam menghadapi masa depan yang mempunyai rintangan. Sehingga dalam mata pelajaran PPKn perlu mengakomodasi berbagai isu-isu baru yang berkaitan dengan kehidupan dalam masyarakat, bangsa, dan negara.

Sehingga rintangan yang aktual harus diperkirakan atau diakomondasikan oleh guru dalam pembelajaran PPKn sebagai upaya penggunaan kembali PPKn berdasarkan semangat reformasi (jika Warga Negara Indonesia tetap berkomitmen PPKn menjadi bagian dalam upaya membentuk manusia Indonesia yang berjiwa demokratis, maka hal ini akan berdampak positif bagi citra bangsa Indonesia dimata bangsa lain di dunia). Dengan demikian, dibutukan guru bidang studi PPKn yang benar-benar mempunyai kompetensi untuk mengembangkan esensi materi pembelajaran kewarganegaraan yang komplek tersebut. Akan tetapi, kenyataan banyak guru PPKn yang belum mengembangkan potensi mereka dalam meningkatkan esensi mata pelajaran PPKn yang kian kompleks. Maka hubungan antara implementasi PPKn yang demokratis dengan pembentukan pribadi peserta didik dalam rangka meningkatakan kesadaran pada nilai-nilai pancasila yang didalamnya mencangkup nilai-nilai demokrasi pancasila dan UUD NRI 1945.

Berdasarkan uraian di atas maka penulis tertarik untuk mengadakan penelitian dengan judul "Implementasi Nilai-Nilai Demokrasi dalam Pembelajaran Pendidikan Pancasila dan Kewarganegaraan di MAN Langke Rembong Ruteng Nusa Tenggarah Timur ( NTT)”.

\section{METODE}

Ditinjau dari datanya bahwasannya pendekatan ini mengunakan pendekatan yang bermutu yakni memperhatikan baik segi. Adapun pendekatan yang memperhatikan baik segi yakni pendekatan dalam menalarkan dan mencari tanu informasi yang ada berkaitan dengan kejadian apa yang dialami oleh subyek penelitian secara memiliki dampak yang baik, di karenakan dalam segi perkataan dan dalam pembahasan akan merangkul pokok pembahasan, pada suatu rancangan khusus dengan dan sebagai kata-kata ilmiah ( Moleong, 2007:6 ).

Sehingga dalam perbuata yang mendekati ini adalah gambaran apa adanya. Penelitian deskriptif yaitu penelitian yang berusaha untuk mencari tau tentang persoalan yang terjadi dalam penelitian, dan bisa menuturkan pemecahan masalah yang ada sekarang berdasarkan data-data. Pendekatan gambaran ini yang digunakan pada penelitian ini bermaksudkan untuk memperoleh informasi yang relevan tentang Implementasi Nilai-nilai Demokrasi dalam 
Pelajaran Pendidikan Pancasila dan Kewarganegaraan di MAN Langke Rembong Ruteng NTT secara mendalam dan menyeluruh. Selain itu, dengan pendekatan kualitatif ini diharapkan bisa memecahkan permasalahan dalam menghadapi rintangan dalam perubahan yang berkaitan dengan Implementasi Nilai-Niai Demokrasi dalam Pelajaran Pendidikan Pancasila dan Kewarganegaraan di MAN Langke Rembong Ruteng NTT.

\section{HASIL DAN PEMBAHASAN}

Berdasarkan kegiatan penelitian yang peneliti lakukan di MAN Langke Rembong Ruteng NTT, diperoleh hasil penelitian mengenai implementasi nilai-nilai demokrasi dalam pembelajaran Pendidikan Pancasila dan Kewarganegaraan di MAN Langke Rembong Ruteng NTT. Di bawah ini merupakan pembahasan dari hasil penelitian yang sudah dipaparkan di atas.

\section{Bentuk Nilai-Nilai Demokrasi dalam} Pembelajaran Pendidikan Pancasila dan Kewarganegaraan di MAN Langke Rembong Ruteng NTT

Berdasarkan Pembahasan bentuk nilai-nilai demokrasi dalam pembelajaran pendidikan pancasila dan kewarganegaraan bisa membentuk kepribadian siswa MAN Langke Rembong Ruteng NTT yang baik dan dapat menyiapkan siswa MAN Langke Rembong Ruteng NTT yang demokratis yaitu siswa yang cerdas, berkeadaban, dan bertanggung jawab bagi kelangsungan, serta berpartisipasi dan mengambil peran secara efektif dalam kehidupan di lingkungan MAN Langke Rembong Ruteng NTT dan di masyarakat yang berkaitan dengan demensi hidup. Seperti yang di sampaikan oleh informan AM di sekoah bahwa bentuk nilai-nilai demokrasi, pada dasarnya, demokrasi merupakan suatu bentuk pemerintahan dari rakyat dan untuk rakyat. Rakyat memiliki hak untuk ikut berpartisipasi, baik berperan aktif maupun pada saat melakukan pengontrolan terhadap kebijakan-kebijakan yang dikeluarkan oleh pemerintah. Selain dari pada itu, dalam lembaga resmi pemerintahan terdapat pemisahan berbagai macam unsur seperti unsur eksekutif, legislatif, maupun unsut yudikatif secara jelas.

Pembentukan nilai-nilai demokrasi, terdapat pengakuan terhadap kehendak rakyat yang dijadikan sebagai landasan dalam legitimasi serta kewenangan pemerintahan (kedaulatan rakyat). Pembentukan nilai-nilai demokrasi ini akan menanamkan nilai-nilai kebenaran, nilai estetika dan nilai indah atau nilai etika/ moral, (Winarno, 2007: 4).

Kehendak tersebut nantinya akan dituangkan dalam suatu iklim politik terbuka, yaitu dengan melaksanakan pemilihan umum yang diadakan secara bebas dan berkala. Tiap-tiap warga negara memiliki hak untuk memilih pihak-pihak yang akan memerintah serta juga dapat menurunkan pemerintahan yang sedang berjalan kapanpun mereka mau. Bentuk nilai-nilai demokrasi adalah tindakan yang dilakukan baik individu-individu, pejabatpejabat, atau kelompok pemerintah atau swasta yang diarahkan pada tercapainya tujuan-tujuan yang telah digariskan dalam keputusan kebijakan politik, Solichin Abdul Wahab (1997.63)

Pembentukan nilai-nilai demokrasi merupakan sebuah upaya dalam menerapkan pengetauhan untuk membentuk nilai-nilai demokrasi pada setiap siswa MAN Langke Rembong Ruteng NTT yang ideal kepada semuah agar mempunyai kecakapan dalam merespon gejala-gejala yang ada di dalam lingkungan sekolah, maupun di lingkungan 
masyarakat, dalam hal ini pembentukan nilai-nilai demokrasi dapat dilakukan dalam berbagai hal salah satunya melalui merespon gejala-gejala atau pelanggaran yang ada dalam lingkungan sekolah, dengan begitu siswa akan menggetauhi bagaimana cara mengatasi masalah atau gejalah yang ada di lingkungan sekolah dan sekaligus memberikan solusi atau motivasi. Penyelesaian pertikaian secara damai dan sukarela, menjamin perubahan secara damai dalam masyarakat dinamis,

pergantian penguasa secara teratur, penggunaan paksaan sedikit mungkin, pengakuan dan penghormatan terhadap keanekaragaman, penegakan keadilan, memajukan ilmu pengetahuan, dan pengakuan penghormatan atas kebebasan, (Mirriam Budiarjo, 2008: 118).

Pembentukan nilai-nilai demokrasi yakni keterbukaan saluran ide dan gagasan yang diberikan kepada siswa untuk mengatasi gejalah atau masalah yang ada, sehingga semua siswa bisa menerima informasi seoptimal mungkin dan bisa memberikan pendapat dalam satu persoalan atau masalah yang terjadi dalam lingkungan sekolah, dan siswa bisa memahami dan mengambil keputusan yang pasti dalam persoalan yang terjadi, baik secara individu-individu dan kelompok dengan kapasitas yang mereka miliki untuk menyelesaikan berbagai persoalan di sekolah. Pembentukan nilai-nilai demokrasi dalam pembelajaran Pendidikan Pancasila dan Kewarganegaraan di MAN Langke Rembong Ruteng NTT melaluhi jalur pendidikan formal. Karena pembentukan nilai-nilai demokrasi dalam pembelajaran kewarganegaraan bagi suatu institusi merupakan proses pembinaan, penanaman, dan pewarisan nilai-nilai kebangsaan dan kenegaraan yang diselenggarakan dalam lingkungan pendidikan, karena dipandang memiliki peranan penting dan strategis dalam pembentukan nilai-nilai demokrasi pada diri siswa MAN Langke Rmbong NTT.

Pembentukan nilai-nilai demokrasi dalam pembelajaran pendidikan pancasila dan kewarganegaraan merupakan suatu usaha sadar dalam membentuk nilai-nilai demokrasi yang bermoral pada setiap Masyarakat, nilai-nilai demokrasi dalam pembelajaran kewarganegaraan bagi suatu institusi merupakan proses pembinaan, penanaman, dan pewarisan nilai-nilai kebangsaan dan kenegaraan yang diselenggarakan dalam lingkungan pendidikan, karena dipandang memiliki peranan penting dan strategis dalam pembentukan nilai-nilai demokrasi, karena bentuk nilai-nilai demokrasi tidak hanya berkenaan dengan materi yang diajarkan oleh guru Pendidikan Pancasila dan Kewarganegaraan (PPKn) kepada siswa, melainkan siswa harus benar-benar memahami bentuk nilai-nilai demokrasi dalam pembelajaran pendidikan pancasila dan kewarganegaraan yang diajarkan atau disampaikan oleh guru didalam ruangan kelas, dan siswa harus menerapkan atau menanamkan nilai-nilai demokrasi yang sudah diajarkan oleh guru PPKn di lingkungan sekolah. Kebebasan dalam berpendapat, kebebasan dalam persurat kabaran, kebebasan dalam berkumpul atau berorganisasi, kebebasan dalam beragama, (Mukram S: 1997).

\section{Implementasi Nilai-Nilai Demokrasi dalam Pembelajaran Pendidikan Pancasila dan Kewarganegaraan di MAN Langke Rembong NTT}

Berdasarkan pembahasan, bahwasannya dalam implementasi nilai-nilai demokrasi dalam pembelajaran pendidikan kewarganegaraan di MAN Langke Rembong Ruteng NTT dapat dikatakan sudah berjalan dengan baik. 
Pelaksanaannya yakni melalui metode diskusi dalam kelas dan ini sudah menjadi kebijakan yang ada dalam pendidikan dan sudah disepakati oleh sekolah. Untuk penerapannya sendiri sudah diupayakan secara maksimal mungkin oleh pihak sekolah. Implementasi nilai-nilai demokrasi dalam Pembelajaran Pendidikan Pancasila dan Kewarganegaraan merupakan kegiatan yang dilakukan secara sadar dan sengaja dalam proses belajar mengajar dengan melaluhi metode diskusi. Sugandi, (2004. 30). Terkait dengan hal tersebut, bahwa nilai-nilai demokrasi dalam pembelajaran itu sangat penting untuk ditanamkan kepada setiap siswa dan siswi MAN Langke Rembong, karena dengan begitu bisa mendorong siswa dan siswi untuk berperilaku yang baik atau yang sesuai dengan apa yang sudah diterapkan dalam nilai-nilai demokrasi tersebut, sehingga bisa membangun dan mengembangkan potensi manusia agar memiliki jiwa atau karakter yang baik, integritas dalam menyampaikan pendapat, dan kompetensi yang bermakna yang efektif.

Implementasi nilai-nilai demokrasi dalam pembelajaran Pendidikan Pancasila dan Kewarganegaraan di MAN Langke Rembong Ruteng NTT tidak hanya patokan terhadap pada guru untuk berbicara dalam menyampaikan materi, tetapi dianjurkan kepada semua siswasiswi untuk menyampaikan pendapat mengenai apa yang mereka ketahui tentang materi yang sesuai dengan apa yang ada dalam pembelajaran Pendidikan Pancasila dan Kewarganegaraan (PPKn) tersebut atau memberikan kebebasan kepada semua siswa untuk berbicara dalam menyampaikan pendapat. Penggunaan metode yang bervariasi akan sangat membantu peserta didik dalam mencapai tujuan pembelajaran. Berikut dikemukakan beberapa metode pembelajaran yang dapat dipilih oleh guru diantaranya: metode demonstrasi, metode inkuiri, metode penemuan, metode eksperimen, metode pemecahan masalah, metode perolehan konsep, metode penugasan, metode ceramah, metode tanya jawab, dan metode diskusi (Hamja 2007: 33).

Implementasi nilai-nilai demokrasi dalam Pembelajaran Pendidikan Pancasila dan Kewarganegaraan ini memberikan kesempatan kepada semua siswa untuk menyampaikan pendapat yang mereka ketauhi tentang pelajaran atau materi, itu merupakan salah satu cara mengimplementasikan nilai-nilai demokrasi dalam pelajaran pendidikan pancasila dan kewarganegaraan (PPKn), sehingga siswa bisa memahami dan sekaligus menerapkan apa yang suda mereka ketauhi implementasi nilai-nilai demokrasi dalam pembelajaran pendidikan pancasila dan kewarganegaraan. Implementasi nilai-nilai demokrasi bisa menumbuhkan nilai-nilai demokrasi dan dapat dipercaya akan membawa kehidupan siswa dan siswi semangat dalam menyampaikan pendapat. Mukram (1997: 43).

Implementasi nilai-nilai demokrasi dalam pembelajaran ini siswa mempunyai sifat egalitarian, selain itu akan menumbuhkan sifat demokrasi yakni menolong dan mencegah tumbuhnya sifat otoriter dalam ruangan kelas disaat pelajaran sedang berjalan. Pendidikan Pancasila dan Kewarganegaraan (PPKn) ini akan menjamin bagi siswa dan siswi menghormati tegaknya HAM dalam berbagi aspek. Implementasi nilai-nilai demokrasi dalam pembelajaran Pendidikan Pancasila dan Kewarganegaraan akan mengimplementasikan tegaknya HAM yang lebih luas bagi setiap siswa dan siswi 
dalam ruangan kelas untuk menyampaikan pendapatnya mengenai materi yang mereka pelajari. Mukram (1997: 35).

Implementasi Nilai-nilai demokrasi dalam pembelajaran Pendidikan Pancasila dan Kewarganegaraan ini akan membantu siswa dan siswi untuk memahami tentang menjadi siswa-siswi yang baik dalam ruangan kelas dan bisa menghormati atau menghargai guru yang sedang menyampaikan materi dalam ruangan. Implementasi nilai-nilai demokrasi dalam pelajaran Pendidikan Pancasila dan Kewarganegaraan dapat memberikan kesempatan sebesar-besarnya bagi siswa dan siswi untuk menggunakan kebebasannya dalam menyampaikan pendapatnya kepada guru,yang berkaitan dengan peajaran Pendidikan Pancasila dan Kewarganegaraan. Hamja (2007: 25).

Implementasi Nilai-nilai Demokrasi dalam pembelajaran Pendidikan Pancasila dan Kewarganegaraan di MAN Langke Rembong Ruteng NTT sudah dilaksanakan dengan baik dan efektit, dan dikembangkan secara efesien. Hal ini terlihat dengan adanya upaya dari sekolah untuk mengimplementasikan nilai-nilai demokrasi dalam pembelajaran Pendidikan Pancasila dan Kewarganegaraan melalui metode diskusi serta memberikan kesempatan pada siswa untuk bermain peran sesuai dengan muatan materi yang diajarkan dengan tujuan agar siswa tidak hanya sekedar tahu untuk mengimplementasikan nilai-nilai demokrasi lebih lanjut siswa diharapkan mengerti secara keseluruhan tentang nilai-nilai demokrasi yang sesungguhnya. Seperti bermain peran penegakan HAM yang baik di Negara Indonesia, dan siswa dianjurkan untuk menyampaikan pendapat berkaitan dengan penegakan HAM yang baik dan benar. Mengimplementasi Nilai-nilai demokrasi ini dapat membantu siswa-siswi
MAN Langke Rembong Ruteng NTT untuk mengembangkan potensi-potensi yang ada dalam dirinya.

\section{Guru Mengatasi Hambatan Dalam} Pembelajaran Pendidikan Pancasila dan Kewarganegaraan Tentang Materi Nilai-Nilai Demokrasi di MAN Langke Rembong Ruteng NTT

Guru mengatasi hambatan dalam pembelajaran Pendidikan Pancasila dan Kewarganegaraan tentang materi nilai-nilai demokrasi yakni dengan memberikan atau mengajarkan cara-cara menerapkan nilainilai demokrasi kepada setiap siswa MAN Langke Rembong Ruteng NTT sebagai salah satu bentuk ilmu pengetahuan dibidang kewarganegaraan. Ini merupakan bentuk upaya untuk menanamkan pada diri siswa MAN Langke Rembong Ruteng NTT, untuk senantiasa bekerja keras dan jangan bergantung pada orang lain, siswa MAN Langke Rembong harus memiliki jiwa cinta dalam menanamkan nilai-nilai demokrasi yang harus diterapkan dalam kehidupan sehari-hari. Guru mengatasi hambatan dalam pembelajaran Pendidikan Pancasila dan Kewarganegaraan tentang materi nilai-nilai demokrasi dengan adanya kerja sama antara guru dan siswa dalam kegiatan pembelajaran Pendidikan Pancasila dan Kewarganegaraan di sekolah, Achmad Sugandi (2004: 18).

Peran Pendidikan Pancasila dan Kewarganegaraan ini untuk mengkaji serta menanamkan kembali nilai-nilai demokrasi kepada semua siswa MAN Langke Rembong Ruteng NTT, karena siswa MAN Langke Rembong merupakan generasi muda yang harus mereka paham tentang betapa pentingnya nilai-nilai demokrasi dalam menanamkan nya serta menerapkannya kembali.

Nilai-nilai demokrasi yaitu nilai yang akan memberikan motivasi kepada semua

Muhammad Nasrullah, dkk. Implementasi Nilai-Nilai Demokrasi dalam Pembelajaran Pendidikan Pancasila dan Kewarganegaraan di Man Langke Rembong Ruteng Nusa Tenggara Timur 
siswa atau semua elemen sekolah yang harus ditanamkan dan diterapkan dalam pendidikan, dan ini merupakan salah satu upaya untuk menanamkan nilai-niali demokrasi kepada peserta didik atau siswa.

Guru mengatasi hambatan dalam pembelajaran Pendidikan Pancasila dan Kewarganegaraan tentang materi Nilai-nilai demokrasi yakni memberikan atau menanamkan nilai kesatuan yang berperan untuk menyatuhkan kembali jiwa-jiwa antara yang satu dengan yang lain serta mengajarkan cara-cara menanamkan pada diri siswa tentang pentingnya rasa persatuan. Persatuan dan kesatuan dalam menanamkan nilai-nilai demokrasi akan menumbuhkan jiwa-jiwa nasionalisme dalam lingkungan masyarakat, Noeng Muhajir, (1993: 33).

Hambatan yang ada dalam pembelajaran Pendidikan Pancasila dan Kewarganegaraan tentang materi nilai-nilai demokrasi tidak akan ada, sehingga materi nilai-nilai demokrasi ini tidak mudah tergoyahkan oleh sebab apapun yang dapat menghancurkannya. Hambatan yang ada dalam materi nilai-nilai demokrasi ini merupakan nilai yang sangat penting untuk diajarkan kepada semua siswa MAN Langke Rembong Ruteng NTT, dan nilainilai demokrasi ini merupakan bagian dari nilai moral menyangkut tentang mana yang benar dan mana yang salah. Karena di dalamnya tercermin akan nilai-nilai kebaiakan yang bersumber dari agama.

Guru mengatasi hambatan dalam pembelajaran pendidikan pancasila dan kewarganegaraan tentang materi nilai-nilai demokrasi di MAN Langke Rembong Ruteng NTT, Guru menekankan dan memberikan motivasi kepada semua siswa MAN Langke Rembong supaya menanamkan sekaligus menerapkan nilai- nilai demokrasi pada diri siswa tersebut, dan guru PPKn memberikan materi tentang nilai-nilai demokrasi ini dengan bersumber kepada agama, karena nilai-nilai demokrasi yang berpatokan terhadap agama, bagian dari nilai kemanusiaan dan moral yang ada dalam ajaran agama, agar siswa bisa benar-benar paham dan bisa menerapkan sesuai dengan apa yang diajarkan. Motivasi dalam membanggun nilai-nilai demokrasi yang bersumber pada Agama merupakan sumber sekaligus penerapan nilai-nilai demokrasi, Mukram (1997: 77).

Guru mengatasi hambatan dalam pembelajaran pendidikan pancasila dan kewarganegaraan tentang materi nilai-nilai demokrasi di MAN Langke Rembong Ruteng NTT yakni guru selalu memberikan motivasi yang baik kepada semua siswa, dan mampu memberikan harapan pada siswa, mampu membuat siswa akuntabel, dan mendorong partisipasi orang tua dalam memajukan kemampuan akademik siswanya, agar siswa tidak lupa dengan nilai-nilai demokrasi, dan siswa selalu menginggat cara-cara menerapkan dan menananmkan nilai-nilai demokrasi di dalam diri dan dalam kehidupan masyrakat. guru yang baik biasa menerima berbagai masukan, risiko, dan tantangan, selalu memberikan dukungan pada siswanya, konsisten dalam kesepakatan-kesepakatan dengan siswa, bijaksana terhadap kritik siswa, menyesuaikan diri dengan kemajuankemajuan siswa, pengajaran yang memperhatikan individu, mampu memberikan jaminan atas kesetaraan partisipasi siswa, mampu menyediakan waktu yang pantas untuk siswa bertanya, cepat dalam memberikan feed back bagi siswa dalam membantu mereka belajar, peduli dan sensitif terhadap perbedaan-perbedaan latar belakang sosial ekonomi dan kultur siswa, dan menyesuaikannya pada 
kebijakan-kebijakan menghadapi berbagai perbedaan.

Guru yang baik juga harus mampu menunjukkan keahlian dalam perencanaan, memiliki kemampuan mengorganisasi kelas sejak hari pertama dia bertugas, cepat memulai kelas, melewati masa transisi dengan baik, memiliki kemampuan dalam mengatasi dua atau lebih aktivitas kelas dalam satu waktu yang sama, mampu memelihara waktu bekerja serta menggunakannya secara efisien dan konsisten, dapat meminimalisasi gangguan, dapat menerima suasana kelas yang ribut dengan kegiatan pembelajaran, memiliki teknik untuk mengontrol kelas, memberi hukuman dengan bentuk yang paling ringan, dapat memelihara suasana tenang dalam belajar, dan tetap dapat menjaga siswa untuk tetap belajar menuju sukses, Hamja (2007: 34).

Guru sebaiknya juga menggunakan model active learning atau belajar aktif, yaitu model pembelajaran yang memberi peluang sangat luas bagi siswa untuk belajar dengan mengurangi porsi guru untuk ceramah. Guru harus dapat memberikan penugasan yang bermakna bagi siswa, baik untuk diskusi, penyelasaian tugas, menyelasaikan masalah atau lainnya. Serta model cooperate learning (belajar secara kooperatif yang tidak hanya belajar bersama, namun saling membantu) melalui diskusi dalam kelompok-kelompok kecil, debat atau bermain peran. Biarkan siswa saling membantu satu sama lain serta saling bertukar informasi yang mereka dapatkan dari hasil akses informasinya. Melalui sebuah diskusi akan terpupuk nilai-nilai demokrasi karena pelaksanaan diskusi sangat memungkinkan siswa berinteraksi dengan siswa yang lain, belajar mengemukakan pendapatnya, menghargai setiap pendapat dan tidak memaksakan pendapatnya kepada orang lain.

\section{SIMPULAN}

Bentuk Nilai-nilai Demokrasi dalam Pembelajaran Pendidikan Pancasila dan Kewarganegaraan di MAN Langke Rembong Ruteng NTT yakni membentukan nilai-nilai demokrasi pada semua siswa demi membangun dan menanamkan jiwajiwa nasionalisme dalam lingkungan pendidikan, dan pembentukan nilai-nilai demokrasi dalam pembelajaran pendidikan pancasila dan kewarganegaraan ini memberikan kesempatan kepada setiap siswa untuk merespon tentang masalah yang terjadi di lingkungan sekolah, sehingga siswa MAN Langke Rembong Ruteng NTT tidak hanya mengetauhi saja, tetapi diharapkan semua siswa memberikan solusi dalam menyelesaikan persoalan yang terjadi dilingkungan sekolah, sehingga siswa bisa mengetauhi cara menyelesaikan masalah yang baik dan benar seperti apa yang ada dalam nilai-nilai demokrasi, dan siswa harus menerapkan atau menanamkan pada diri utuk diterapkan dalam kehidupan masyarakat. Sehingga dalam pembentukan nilai-nilai demokrasi dalam pembelajaran pendidikan pancasila dan kewarganegaraan di MAN Langke Rembong Ruteng NTT tidak ada factor penghambat. Dikarenakan pihak sekolah dan Guru PPKn saling bekerja sama, untuk memberikan atau membanggun, menanamkan serta membentuk nilai-nilai demokrasi dalam pembelajaran pendidikan pancasila dan kewarganegaraan di MAN Langke Rembong Ruteng NTT.

Implementasi Nilai-Nilai Demokrasi dalam Pembelajaran Pendidikan Pancasila dan Kewarganegaraan di MAN Langke Rembong NTT sudah dilaksanakan dengan baik dan efektit, dan dikembangkan dengan efesien. Hal ini terlihat dengan adanya upaya dari sekolah berupaya mengembangkan nilai-nilai demokrasi

Muhammad Nasrullah, dkk. Implementasi Nilai-Nilai Demokrasi dalam Pembelajaran Pendidikan Pancasila dan Kewarganegaraan di Man Langke Rembong Ruteng Nusa Tenggara Timur 
dalam pembelajaran Pendidikan Pancasila dan Kewarganegaraan melalui metode diskusi serta memberikan kesempatan pada siswa untuk bermain peran sesuai dengan muatan materi yang diajarkan dengan tujuan agar siswa tidak hanya sekedar tahu tetapi juga mampu menjalankan secara kontekstual. Melalui nilai-nilai demokrasi ini dapat membantu siswa-siswi untuk terus mengembangkan potensi-potensi yang ada di dalam dirinya;

Guru mengatasi hambatan dalam Pembelajaran Pendidikan Pancasila dan Kewarganegaraan tentang materi Nilai-nilai Demokrasi di MAN Langke Rembong Ruteng NTT yakni guru selalu memberikan motivasi terhadap setiap siswa, agar semua siswa tidak ragu dalam menerapkan nilainilai demokrasi, agar hambatan dalam pembelajaran pendidikan pancasila dan kewarganegaraan tentang materi nilai-nilai demokrasi tidak ada, dan bisa berjalan sesuai dengan apa yang di inginkan atau sesuai dengan apa yang ada di dalam pembelajaran pendidikan pancasila dan kewarganegaraan. Dan Guru senantiasa bekerja keras untuk memberikan motivasi dan guru selalu mengucapkan kepada semua siswa jangan bergantung pada orang lain, siswa MAN Langke Rembong harus memiliki jiwa cinta dalam menanamkan nilai-nilai demokrasi yang harus diterapkan dalam kehidupan seharihari. Dan adanya peran pendidikan pancasila dan kewarganegaraan ini untuk mengkaji serta menanamkan kembali nilainilai demokrasi kepada semua siswa MAN Langke Rembong Ruteng NTT, karena siswa MAN Langke Rembong merupakan generasi muda yang harus mereka paham tentang betapa pentingnya nilai-nilai demokrasi dalam menanamkan nya serta menerapkannya kembali.
Berdasarkan hasil penelitian, dikemukakan beberapa saran yang dapat dijadikan masukan untuk lebih meningkatkan kinerja sekolah, diantaranya sebagai berikut: Bentuk nilai-nilai demokrasi dalam pembelajaran pendidikan pancasila dan kewarganegaraan di MAN Langke Rembong Ruteng NTT bisa membangun jiwa-jiwa nasionalisme ( cintah terhadap tanah air) kepada semua siswa MAN Langke Rembong Ruteng NTT agar bisa membentuk serta menanmkan dan menerapkan nilai-nilai demokrasi dalam kehidupan sehari-hari, baik dalam kehidupan lingkungan pendidikan maupun dalam lingkungan masyarakat.

Implementasi Nilai-nilai Demokrasi dalam Pembelajaran Pendidikan Pancasila dan Kewarganegaraan di MAN Langke Rembong NTT Nilai-nilai demokrasi perlu ditanamkan pada generasi muda agar terbentuk generasi yang demokratis, dan diharapkan kepada semua siswa untuk menerapkan dalam kehidupan sehari, sesuai dengan apa yang diingginkan oleh guru, dan apa yang diharapkan oleh Pancasila, dan UUD 1945.

Guru mengatasi hambatan dalam Pembelajaran Pendidikan Pancasila dan Kewarganegaraan tentang materi Nilai-nilai Demokrasi di MAN Langke Rembong Ruteng NTT yakni guru yang baik harus memiliki sifat-sifat antusias, stimulatif, mendorong siswa untuk maju, semangat berorientasi pada tugas dan pekerja keras, toleran, sopan, dan bijaksana, bisa dipercaya atau fleksibel dan mudah menyesuaikan diri atau demokratis, penuh harapan bagi siswa, tidak semata mencari reputasi pribadi, mampu mengatasi stereotipe siswa, bertanggung jawab terhadap kegiatan belajar siswa, mampu menyampaikan perasaannya, dan memiliki pendengaran yang baik, dan 
menyampaikan hal-hal positif kepada siswa MAN Langke Rembong Ruteng NTT menjalankan kebebasan yang bertanggung jawab secara moral, dan berjiwa religius kepada Tuhan Yang Maha Esa, mewujudkan rasa keadilan sosial, pengambilan keputusan dengan musyawarah mufakat, mengutamakan persatuan nasional dan kekeluargaan, menjunjung tinggi tujuan dan cita-cita nasional.

\section{DAFTAR PUSTAKA}

Abdul Wahab, Solichin. 1997. Pengantar Analisis Kebijakan Negara. Jakarta: Rineka Cipta

Abdul Wahab, Solichin. 2004. Implementasi Kebijakan Negara. Sinar Grafika. Jakarta

Budiarjo. 2008. Pengantar Pendidikan Demokrasi. Jakarta : Bumi Aksara

Hamja. 2007. Metode Pembelajaran. Jakarta: PT Rineka Cipta.

Moleong. Lexcy. 2007. Metode Penelitian Kualitatif. Bandung : PT Remaja Rosdakarya.

Muhajir, Noeng. 1993. Ilmu Pendidikan dan Perubahan Suatu Teori Pendidikan. Yokyakarta: Rakesarasin

Mukram. 1997. Budaya Demokrasi Indonesia. Bandung : PT Remaja Rosdakarya.

Sugandi, Achmad, dkk. 2002. Belajar dan Pembelajaran. Semarang: IKIP PRESS.

Winarno. 2007. Pendidikan Kewarganegaraan. Jakarta: PT Bumi Aksara 